\title{
RED CELL GLYOXALASE I POLYMORPHISM AMONG THE SELECTED TRIBES OF THE SUDAN
}

\author{
P.K. LAHA., N. SAHA, and R.A. BAYOUMI \\ Faculty of Medicine, University of Khartoum, \\ P.O.B. 102, Khartoum, Sudan
}

\begin{abstract}
Summary 850 unrelated subjects of both sexes from several tribes of Arab and Negroid origin in Sudan were investigated for the distribution of red cell GLO I phenotypes. The estimated frequency of $G L O^{1}$ were from 0.3804 to 0.4121 in tribes of Arab extraction and 0.3000 to 0.3732 in tribes of Negroid origin. Hwazma tribe claiming Arab descent had a low frequency of $G L O^{1}(0.2548)$. There was a significant deviation of HardyWeinberg equilibrium in the gene frequencies with excess of homozygosity in the present population groups probably due to the presence of high degree of inbreeding. There was no significant association of GLO phenotypes with haemoglobin types.
\end{abstract}

\section{INTRODUCTION}

Red cell glyoxalase I [EC 4.4.1.5] exhibit genetic polymorphism in humans (Kömpf et al., 1975). Three common phenotypes designated GLO 1, GLO 2-1 and GLO 2 are under genetic control of two autosomal co-dominant allele GLO and $G L O^{2}$. Recently a third silent allele $G L O^{\circ}$ has been described (Rittner and Weber, 1978). No other rare variant has been encountered in the course of population studies in various parts of the world. The GLO gene has been assigned to chromosome 6, near the HLA locus using man-mouse somatic cell hybrids (Weitkamp and Guttormsen, 1975; Bender and Grzschik, 1976). The polymorphism of GLO I has been described first in a German population by Kömpf et al., (1975). Since then, several populations of the world have been studied for GLO I gene frequencies. An up-to-date review of the literature is presented in Table 1. The gene frequencies of $G L O^{1}$ vary widely in the different populations studied with the highest frequency reported in Caucasians and very low frequencies in Japanese, Australian Aborigines and Papua New Guineans. In general there is sparsity of data on GLO polymorphism in Negroes.

There are only two reports from Africa-one in Jali of Gambia (Parr et al., 
Table 1. Gene frequencies of $G L O^{1}$ in various populations reported in literature.

\begin{tabular}{|c|c|c|c|c|}
\hline \multicolumn{2}{|c|}{ Population } & \multirow[t]{2}{*}{$\mathrm{n}$} & \multicolumn{2}{|r|}{$G L O^{1} \quad$ Reference } \\
\hline \multicolumn{4}{|l|}{ A. WHITES } & \\
\hline \multicolumn{2}{|c|}{ Americans } & 101 & 0.42 & Weitkamp and Guttormsen (1975) \\
\hline \multicolumn{2}{|l|}{ Dutch } & 757 & 0.454 & Meera Khan and Doppert (1976) \\
\hline \multirow{2}{*}{\multicolumn{2}{|c|}{ English London }} & 200 & 0.42 & Bagster et al. (1975) \\
\hline & & 296 & 0.44 & Bagster and Parr (1976) \\
\hline \multirow{2}{*}{\multicolumn{2}{|c|}{$\begin{array}{c}\text { Germans Southwestern } \\
",\end{array}$}} & 655 & 0.427 & Kömpf and Bissbort (1975) \\
\hline & & 169 & 0.39 & Kömpf et al. (1975) \\
\hline \multicolumn{2}{|c|}{$" \quad$ West Berlin } & 548 & 0.377 & Martin and Ott (1976) \\
\hline \multicolumn{2}{|c|}{$" \quad$ Hessen } & 361 & 0.439 & Kühnl et al. (1977) \\
\hline \multicolumn{2}{|c|}{$" \quad$ Rostock } & 233 & 0.425 & Stohlmacher and Haferland (1977) \\
\hline \multicolumn{2}{|c|}{$" \quad$ Cologne } & 1,075 & 0.451 & Mauff et al. (1978) \\
\hline \multicolumn{2}{|c|}{$" \quad$ Southern } & 1,025 & 0.424 & Berg et al. (1977) \\
\hline \multicolumn{2}{|c|}{ Lapps } & 184 & 0.304 & Olaisen et al. (1976) \\
\hline \multicolumn{2}{|c|}{ Newfoundlanders } & 226 & 0.34 & Carter et al. (1978) \\
\hline \multicolumn{2}{|c|}{ Norwegians } & 216 & 0.442 & Olaisen et al. (1976) \\
\hline \multicolumn{2}{|c|}{ Polish } & 1,310 & 0.557 & Koziol and Dobosz (1978) \\
\hline \multicolumn{2}{|l|}{ Swiss } & 619 & 0.444 & Pffügshaupt et al. (1978) \\
\hline \multicolumn{5}{|c|}{ B. NON-WHITES } \\
\hline \multicolumn{2}{|l|}{ Iranians } & 115 & 0.400 & Ghosh (1977) \\
\hline \multirow{7}{*}{ Jews: } & Iranian & 85 & 0.2294 & Golan et al. (1979) \\
\hline & Iraqi & 203 & 0.2710 & Golan et al. (1979) \\
\hline & Ashkenazi & 191 & 0.3010 & Golan et al. (1979) \\
\hline & Balkan & 145 & 0.3101 & Golan et al. (1979) \\
\hline & Yemenite & 134 & 0.3321 & Golan et al. (1979) \\
\hline & Turkish & 151 & 0.3344 & Golan et al. (1979) \\
\hline & Egyptian & 63 & 0.3968 & Golan et al. (1979) \\
\hline Arabs I & Israel & 205 & 0.2951 & Golan et al. (1979) \\
\hline \multicolumn{5}{|c|}{ Asiatic Indians: } \\
\hline & West & 1,019 & 0.279 & Ghosh (1977) \\
\hline & East & 268 & 0.213 & Ghosh (1977) \\
\hline & North & 505 & 0.231 & Ghosh (1977) \\
\hline & South & 154 & 0.230 & Ghosh (1977) \\
\hline \multicolumn{2}{|c|}{ Indians Kuala Lumpur } & 183 & 0.287 & Teng et al. (1978) \\
\hline \multicolumn{2}{|c|}{ Chinese Singapore } & 149 & 0.154 & Ghosh (1977) \\
\hline Chinese & Kuala Lumpur & 115 & 0.200 & Teng et al. (1978) \\
\hline Malays & Kuala Lumpur & 294 & 0.196 & Teng et al. (1978) \\
\hline Sumatra & & 340 & 0.188 & Ghosh (1977) \\
\hline Western & Pacific Area & 1,947 & 0.220 & Ghosh (1977) \\
\hline Japanese & e Tokyo & 572 & 0.088 & Harada and Misawa (1976) \\
\hline$"$ & Tokyo & 414 & 0.053 & Hashimoto et al. (1978) \\
\hline$"$ & Mie & 346 & 0.079 & Kuwata and Ishimoto (1976) \\
\hline$"$ & Yokohama & 493 & 0.068 & Yoshida et al. (1977) \\
\hline Americal & in Negroes & 108 & 0.28 & Weitkamp and Guttormsen (1975) \\
\hline South $\mathrm{Al}_{\mathrm{r}}$ & merican Indians & 259 & 0.297 & Ghosh (1977) \\
\hline Jali Ga & ambia & 506 & 0.28 & Parr et al. (1977) \\
\hline
\end{tabular}




$\begin{array}{lrrl}\text { South African Negroids } & 843 & 0.259 & \text { Bender et al. }(1977) \\ \text { Philippine Negrito } & 128 & 0.244 & \text { Omoto et al. (1978) } \\ \text { Australian Aborigines } & 783 & 0.025 & \text { Ghosh (1977) } \\ \text { Papua New Guineans } & 1,757 & 0.030 & \text { Ghosh }(1977) \\ \text { Sudanese: Arab Extraction } & 523 & 0.403 & \text { Present report } \\ \quad \text { Negroids } & 172 & 0.360 & \text { Present report } \\ \quad \text { Hawzma } & 155 & 0.255 & \text { Present report }\end{array}$

1977) and another in South African Negroids (Bender et al., 1977). In addition, there is one report in American Negroes (Weitkamp and Guttormsen, 1975).

We present here data on the distribution of red cell GLO I polymorphism among selected tribes of the Sudan-both of Arab and Negroid extractions.

\section{MATERIALS AND METHODS}

Eight hundred and fifty subjects of both sexes, selected at random, were investigated for the distribution of red cell GLO I polymorphism by the method of Parr et al. (1977). This sample comprised of 371 subjects of Arab descent, 172 subjects of Negroid origin and 307 subjects of mixed population whose tribal origin was not recorded. The first group of Arab descent had 138 subjects from Ga'ali tribe of Northern Sudan, 155 from Hwazma tribe of Western Sudan, and 78 from smaller tribes sampled in Khartoum. The second group of negroid origin had 142 Nuba from Nuba mountains and 30 from smaller tribes sampled in Khartoum. A subsamples of 532 subjects were also examined for haemoglobin types by starch gel electrophoresis using TEB buffer system at pH 8.6. Data on inbreeding was collected as there is high degree of inbreeding present in this region.

\section{RESULTS AND DISCUSSION}

The results of GLO I typing in selected tribes from the Sudan are presented in Table 2. The overall gene frequency of $G L O^{1}$ was found to be 0.3676 with intertribal variations. The gene frequencies for $G L O^{1}$ were $0.3804,0.4103$ and 0.4121 respectively in three groups of population of $\mathrm{Arab}$ origin namely (i) Ga'ali tribes, (ii) a group of smaller tribes, and (iii) a mixed population of Northern Sudan of unknown tribes. The gene frequencies in these three groups are similar to the gene frequencies reported for Caucasians and Iranians (Table 1). The negroid group comprised of Nuba and a smaller group of other tribes has GLOI frequencies of 0.3732 and 0.3000 respectively which are lower than those in Arab tribes and higher than that in Western and Southern Africans (Parr et al., 1977; Bender et al., 1977). This is consistent with the findings on other genetic markers in this population (Saha et al., 1978 and 1979; Bayoumi and Saha, unpublished). However, the Hwazma tribe claiming to be of Arab origin has a lower frequency of $G L O^{1}(0.2548)$ 
Table 2, Distribution of the red cell GLO phenotypes and gene frequencies in selected tribes of the Sudan.

\begin{tabular}{|c|c|c|c|c|c|c|c|c|c|}
\hline \multirow[b]{3}{*}{ Tribes } & \multirow[b]{3}{*}{$n$} & \multicolumn{6}{|c|}{ GLO Phenotypes } & \multirow[b]{3}{*}{$G L O^{\mathrm{I}}$} & \multirow[b]{3}{*}{$X_{2}^{1}$} \\
\hline & & \multicolumn{2}{|c|}{$1-1$} & \multicolumn{2}{|c|}{$2-1$} & \multicolumn{2}{|c|}{$2-2$} & & \\
\hline & & $\begin{array}{r}n \\
\text { obs. }\end{array}$ & $\begin{array}{c}n \\
\text { expc. }\end{array}$ & $\begin{array}{c}n \\
\text { obs. }\end{array}$ & $\begin{array}{c}n \\
\text { expc. }\end{array}$ & $\begin{array}{c}n \\
\text { obs. }\end{array}$ & $\begin{array}{c}n \\
\text { expc. }\end{array}$ & & \\
\hline Ga'ali & 138 & 38 & 20.0 & 29 & 65.0 & 71 & 53.0 & 0.3804 & 42.20 \\
\hline $\begin{array}{l}\text { Smaller tribes } \\
\text { of Arab origin }\end{array}$ & 78 & 16 & 13.1 & 32 & 37.8 & 30 & 27.1 & 0.4103 & 1.84 \\
\hline Nuba & 142 & 32 & 19.8 & 42 & 66.4 & 68 & 55.8 & 0.3732 & 19.15 \\
\hline $\begin{array}{l}\text { Smaller tribes } \\
\text { of Negro origin }\end{array}$ & 30 & 1 & 2.7 & 16 & 12.6 & 13 & 14.7 & 0.3000 & 2.19 \\
\hline Hwazma & 155 & 17 & 10.1 & 45 & 58.8 & 93 & 86.1 & 0.2548 & 8.50 \\
\hline $\begin{array}{l}\text { Mixed population } \\
\text { (tribes unrecorded) }\end{array}$ & 307 & 59 & 52.1 & 135 & 148.8 & 113 & 106.1 & 0.4121 & 2.64 \\
\hline Total & 850 & 163 & 114.9 & 299 & 395.2 & 388 & 339.9 & 0.3676 & 50.37 \\
\hline
\end{tabular}

Table 3. Distribution of the red cell GLO phenotypes in relation to haemoglobin types.

\begin{tabular}{|c|c|c|c|c|c|c|c|c|c|c|}
\hline \multirow[t]{3}{*}{ Tribe } & \multicolumn{6}{|c|}{ Haemoglobin A } & \multicolumn{4}{|c|}{ Abnormal haemoglobins } \\
\hline & \multirow{2}{*}{$n$} & \multicolumn{4}{|c|}{ GLO phenotypes } & \multirow{2}{*}{$n$} & \multicolumn{4}{|c|}{ GLO phenotypes } \\
\hline & & $\overline{1-1}$ & $2-1$ & $2-2$ & $G L O^{1}$ & & $1-1$ & $2-1$ & $2-2$ & $G L O^{1}$ \\
\hline Hwazma & 113 & 12 & 34 & 67 & 0.2566 & 42 & 5 & 11 & 26 & 0.2500 \\
\hline Others & 367 & 76 & 121 & 170 & 0.3719 & 10 & 2 & 5 & 3 & 0.4500 \\
\hline Total & 480 & 88 & 155 & 237 & 0.3448 & $52^{\mathrm{a}}$ & 7 & 16 & 29 & 0.2885 \\
\hline
\end{tabular}

a $\mathrm{AS}-45, \quad \mathrm{SS}-3, \quad \mathrm{AO}-3, \quad \mathrm{~A}_{2}-1$

which is more like Negro frequency. Similar gene frequency has been reported from Indian subcontinent (Ghosh, 1977). This tribe has also a high frequency of $\mathrm{Hb}^{\mathrm{s}}$ (Bayoumi and Saha, unpublished) which suggests a Negroid origin of this tribe.

There was a significant deviation of Hardy-Weinberg equilibrium in the gene frequency distribution of $\mathrm{GLO}^{1}$ in these tribes with excess of homozygosity. This may be due to the presence of high degree of inbreeding in the population except in Nuba tribe. However the presence of inbreeding in this tribe could not be ruled out completely as this tribe lived in seclusion in the Nuba mountains from prehistoric time completely cut off due to the inaccessibility of this region. Similar deviation of Hardy-Weinberg equilibrium in the distribution of placental alkaline phosphatase was observed in a random sample of Sudanese mothers (Saha et al., 1979).

Table 3 shows the distribution of GLO phenotypes in 532 samples where haemoglobin types were analysed. There was no significant difference in the distribu- 
tion of GLO phenotypes in relation to haemoglobin types. This is in conformity with the observation of Parr et al. (1977) in Jali of Gambia.

\section{REFERENCES}

Bagster, I.A. and Parr, C.W. 1976. Human erythrocyte glyoxalase I polymorphism. J. Physiol. 256: 56-57.

Bagster, I.A., Parr, C.W., and Welch, S.G. 1975. Exythrocyte glyoxalase I polymorphism in an African and English population. FEBS Lett. 60: 336-337.

Bayoumi, R. and Saha, N. A genetic study among the inhabitants of the Nuba mountains of the Sudan (under publication).

Bender, K., Frank, R., and Hitzeroth, H.W. 1977. Glyoxalase I polymorphism in South African Bantu-speaking Negroids. Hum. Genet. 38: 223-226.

Bender, K. and Grzschik, K.H. 1976. Possible assignment of the glyoxalase (GLO) gene to chromosome 6 using a man-mouse somatic cell hybrids. Hum. Genet. 31: 341-345.

Berg, K., Rodewald, A., Schwazfischer, F., and Wischerath, H., 1977. Population genetics of glyoxalase I [EC 4.4.1.5] in human erythrocytes. Z. Rechtsmedizin 79: 13-15.

Carter, N.D., West, G.M., Barnard, J.M., Farid, N.R., Larsen, B., and Marshall, W.H. 1978. Linkage of Glyoxalase I and HLA in two Newfoundland communities. Hum. Hered. 28: $397-400$.

Ghosh, A.K. 1977. Polymorphism of red cell Glyoxalase I. With special reference to South and Southeast Asia and Oceania. Hum. Genet. 45:91-96.

Golan, R., Ben-Ezzer, J., and Szeinberg, A. 1979. Erythrocyte glyoxalase I polymorphism in several population groups in Israel. Hum. Hered. 29: 57-60.

Harada, S. and Misawa, S. 1976. Red cell glyoxalase I [EC 4.4.1.5] polymorphism in Japanese. Kyorin Med. J. 7: 21-24.

Hashimoto, M., Harada, S., and Omoto, K. 1978. Red cell glyoxalase I polymorphism in Japanese. Confirmation of a low $G L O^{1}$ frequency. Jpn. J. Hum. Genet. 23: 139-143.

Kömpf, J., Bissbort, S., Gussmann, S., and Ritter, H. 1975. Polymorphism of red cell Glyoxalase I [EC 4.4.1.5]. A new genertic marker in man. Hum. Genet. $27: 141-143$.

Kömpf, J. and Bissbort, S. 1975. Population genetics of red cell glyoxalase I [EC 4.4.1.5]. Gene frequencies in South-Western Germany. Hum. Genet. 28: 175-176.

Koziol, P. and Dobosz, T. 1978. GLO Polymorphism in two Polish population samples. Hum. Genet. 45: 77-79.

Kühnl, P., Schwabenland, R., and Spielmann, W. 1977. Investigations on the polymorphism of glyoxalase I [EC 4.4.1.5] in the populations of Hessen, Germany. Hum. Genet. 38: 99-106.

Kuwata, M. and Ishimoto, G. 1976. The distribution of red cell uridine monophosphate kinase (UMPK) and glyoxalase I (GLO) phenotypes in a Japanese population. Jpn. J. Legal Med. 30: 76-79.

Martin, W. and Ott, A. 1976. Zur Darstellung der Glyoxalase I under besonderer Berucksichtigung der Instabilitat des Enzyme. Arztl. Lab. 9: 293.

Mauff, G., Wachauf, P., Schaal, K.P., and Pulverer, G. 1978. GLO I and Bf phenotype distribution in a West German population sample. Hum. Hered. 28: 431-434.

Meera Khan, P. and Doppert, B.A. 1976. Rapid detection of glyoxalase I (GLO) on cellulose acetate gel and distribution of GLO variants in a Dutch population. Hum. Genet. 34: 53-56.

Olaisen, B., Teisberg, P., and Jonassen, R. 1976. GLO polymorphism in Norway. Hum. Hered. 26: $454-457$.

Omoto, K., Misawa, S., Harada, S., Sumpaico, J.S., Medado, P.M., and Ogonuki, H. 1978. Population genetic studies of the Phillipine Negritos. I. A pilot survey of red cell enzyme and serum protein groups. Am. J. Hum. Genet. 30: 190-201. 
Parr, C.W., Bagster, I.A., and Weich, S.G. 1977. Human red cell glyoxalase I polymorphism. Biochem. Genet. 15: 109-133.

Pflügshaupt, R., Scherz, R., and Butler, R. 1978. Human red cell glyoxalase I polymorphism in the Swiss population: phenotype frequency and a simplified technique. Hum. Hered. 28: 235-237. Rittner, Ch. and Weber, W. 1978. Evidence of a "Silent Allele" GLO ${ }^{\circ}$ at the glyoxalase I locus. Hum. Genet. 42: 315-318.

Saha, N., Gumaa, K.A., Samuel, A.P.W., and El-Naeim, H. 1979. Placental alkaline phosphatase in a Sudanese population-polymorphism and enzyme activity. Hum. Biol. in press.

Saha, N., Samuel, A.P.W., Omer, A., Ahmed, M.A., Hussein, A.A., and El Nour Gaddoura. 1978. A study of some genetic characteristies of the population of the Sudan. Ann. Hum. Biol. 5: 569-575.

Stohlmacher, P. and Haferland, W. 1977. On the population genetics of the red cell glyoxalase I (GLO). Hum. Genet. 39: 303-304.

Teng, Y.S., Tan, S.G., Ng, T., and Lopez, C.G. 1978. Red cell glyoxalase I and placental aconitase polymorphism in three major ethnic groups of Malaysia. Jpn. J. Hum. Genet. 23: 211-215.

Weitkamp, L.R. and Guttormsen, S.A. 1975. Genetic linkage of a locus for erythrocyte Glyoxalase (GLO) with HLA and BF. In: Proceedings of the Third International Conference on Human Gene mapping, Baltimore. Birth Defects: Original Article Series (The National Foundation, New York). pp. 364-366.

Yoshida, H., Kageyama, T., Watanabe, Y., Abe, T., and Ishikawa, F. 1977. Studies on the frequencies of red cell glyoxalase I (GLO) in a Japanese population (residents in Yokohama) and determination of the GLO type from stale bloods. Rep. Natl. Res. Inst. Police Sci. 30: 94-96.

Reprints request: Prof. N. Saha, Department of medical Genetics, University of Umeå, S-90185 Umeå, Sweden. 